\title{
Searching for the Meaning of Probiotics in the Non-Medical Literature
}

\section{Tiara Dusselier and Ger Rijkers*}

Department of Sciences, University College Roosevelt, Middelburg, The Netherlands

*Corresponding author: Ger T Rijkers, Department of Sciences, University College Roosevelt, P.O. Box 94, 4330 AB Middelburg, The Netherlands, Tel: +31(0)118655500, Fax:+31(0)118655508, E-mail: g.rijkers@ucr.nl

When consumers are looking for probiotics, what are they looking for? Probiotics are defined as "live microorganisms which when administered in adequate amounts confer a health benefit on the host". This definition was the end product of an Expert Consultation of a group of international scientists, invited in 2001 by and on behalf of the Food and Agriculture Organization of the United Nations (FAO) and the World Health Organization (WHO) to debate the (then) emerging field of probiotics [1]. Twelve years later, in 2013, an expert panel was convened by the International Scientific Association for Probiotics and Prebiotics to discuss the field of probiotics, and re-view its definition. Apart from a minor grammatical correction as "live microorganisms that when administered etc." the definition was maintained and reconfirmed [2].

The question is whether the definition of probiotics also is relevant and sufficient for the general public to understand what they actually are. In general, the definition of a certain object or phenomenon can be quite difficult to understand. For instance, the definition of a straight line ("the path of shortest distance between two points") is hard to understand without the relevant context (The shortest distance from work to home really never is a straight line). Likewise, the definition of probiotics may be difficult to understand without the relevant (micro)biological context.

When searching for the meaning of "probiotics" in Google, over $68,900,000$ results show up in 0.56 seconds (assessed November 29, 2018). An analysis of Google searches for probiotics indicates that since 2004 the relative frequency of this search (as compared to "antibiotics") has increased from $10 \%$ to $30 \%$ (Figure 1). Probiotics is a relatively new word that first appeared in the general literature around 1980, as compared to the word antibiotics with 40 years longer history (Figure 2). The paradoxical situation is that despite this information overload resulting from a Google search, it is difficult to obtain reliable, unbiased information. Google trend analysis shows that the Number 1 question asked is "What are probiotics". Not too long ago, one turned to a dictionary to search for the meaning of a given word. However, for recent words, and given the long period between release of new editions, printed versions of dictionaries may not be the first choice anymore.

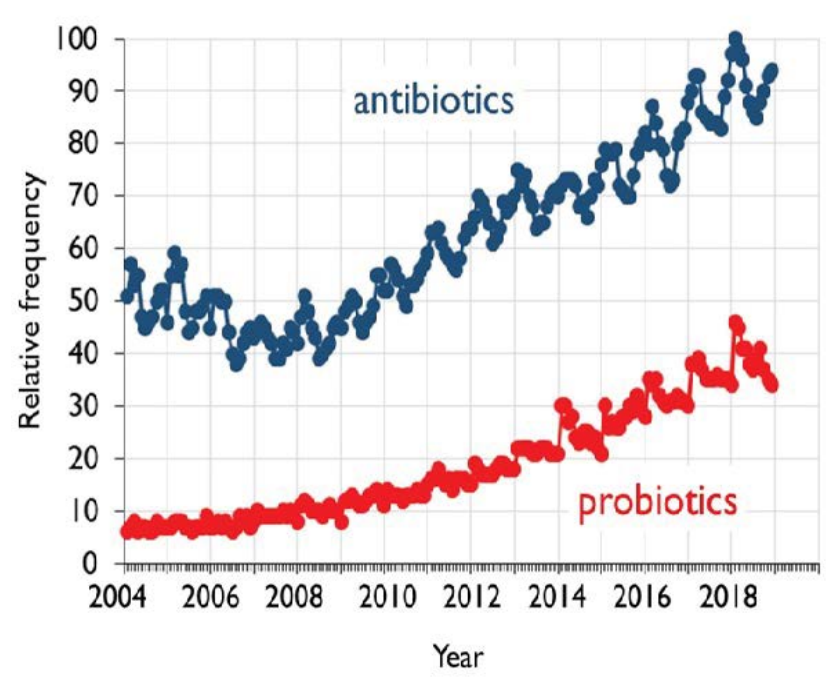

Figure 1: Relative frequencies of the use of the words "antibiotics" and "probiotics" in Google searches. Data derived from Google Trends (https://trends.google. com/trends/explore?geo=US\&q=probiotics, antibiotics), accessed November 29, 2018. 
Online versions of established (printed) dictionaries can be a more up-to-date alternative, next to "online only" dictionaries. We have analyzed whether the word "probiotics" is included in printed and online available (English) dictionaries, and whether the description matched with the definition of probiotics. For this analysis we have compared the description of "probiotics" with that of "antibiotics".

The adequacy of the various descriptions of probiotics were analyzed by a matrix derived from the definition of probiotics (Figure 3). On average, the descriptions of the online only dictionaries were more complete than the online versions of printed dictionaries $(58 \%$ and $29 \%$, respectively, $p<0.05$ ). The characteristic of probiotics that they are live bacteria was never mentioned in the printed versions of dictionaries and occasionally in online dictionaries. The "adequate amounts" part of the definition was never mentioned at all. In case the scope

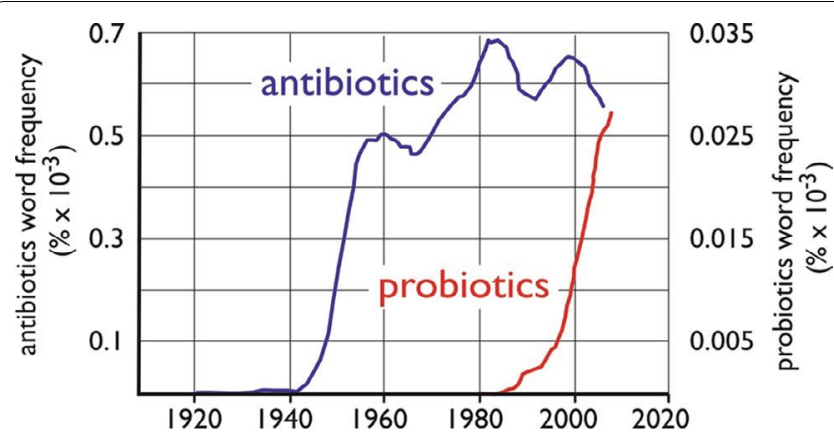

Figure 2: Frequency of the use of the words "antibiotics" and "probiotics" in general literature. Please note the different $\mathrm{Y}$-axes for antibiotics (left $\mathrm{Y}$-axis) and probiotics (right Y-axis). Data derived from Google Ngrams (https:// books.google.com/ngrams), accessed October 29, 2018.

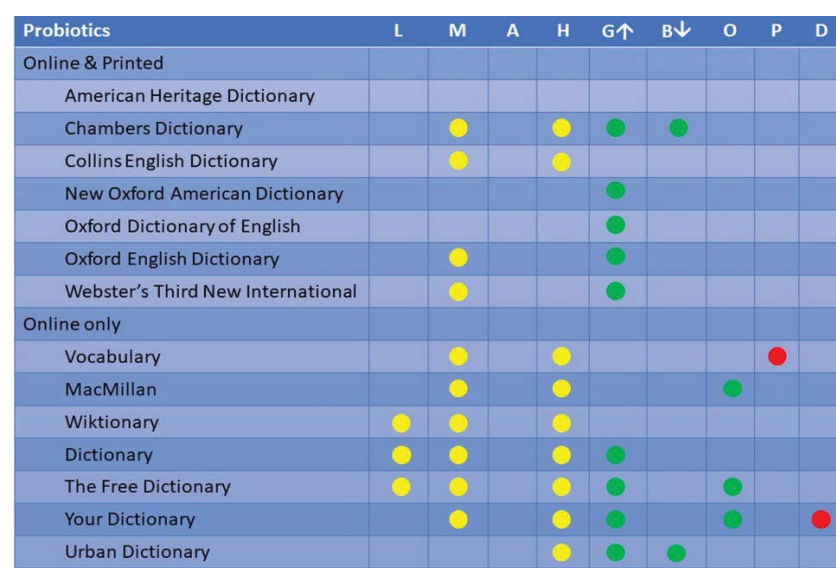

Figure 3: Analysis of the description of "probiotics" in online versions of printed dictionaries and in online only dictionaries. Yellow dots indicate whether the following components of the definition of probiotics are included in the description: Live (L) microorganisms (M), when administered in an adequate amount $(A)$ have a health benefit on the host $(H)$. Green dots used for functionality of probiotics: stimulation of beneficial bacteria (good; G个), inhibition of pathogens (bad; $B \downarrow)$ or other health effect (O). Red dots indicate that the description of probiotics is related to plants $(P)$ or doubts are expressed in the description ("presumed", "supposed") (D). of the health benefit was indicated, this mostly reflected the digestive system and specifically the stimulatory effect on (other) beneficial bacteria. The stimulatory effect of probiotics on the immune system was not mentioned in dictionaries. Inhibition of potential pathogens was only indicated twice. In this context, it should be mentioned that the European Food Safety Authority, in their evaluation of health claim applications for probiotics, do not consider the stimulation of beneficial bacteria to be a health effect [3]. However, EFSA indirectly allowed almost all probiotics by QPS list. Inhibition of potential pathogens is considered to be a (potential) health benefit, if supported by additional evidence [3].

With regard to "antibiotics", the description in the online versions of printed dictionaries was slightly (but not significantly) better or (more) complete than online only dictionaries ( $63 \%$ and $49 \%$, respectively, $p=0.47$ ).

In some of the online dictionaries (Vocabulary. com www.vocabulary.com, Wordweb Online www. wordwebonline.com) the description of a probiotic includes the phrase: "often considered to be a plant". This apparently is caused by the misinterpretation of the words "gutflora" and "microflora" (see also Figure 4). In addition, before the word probiotic was introduced to describe bacteria with a beneficial effect, the term had a completely different meaning. The term probiotic, or prebiotic, was used to describe the geological period before there was any form of life on earth [4]. The latter meaning can still be found in older versions of printed dictionaries, such as the 1989 second edition of the Oxford English Dictionary (Supplementary Table 1 and Supplementary Table 2).

It can be concluded that within online dictionaries, from both online only as well as the online version of a printed dictionary, the term "probiotic" can be found. The descriptions are a mixture of (parts) of the definition and may include functionality and source

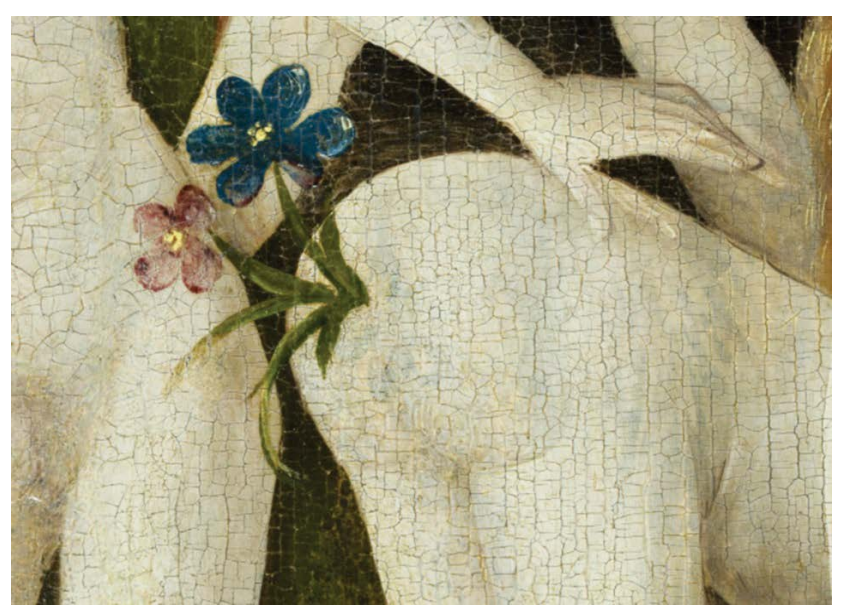

Figure 4: Detail of the painting The Garden of Earthly Delights by Jheronimus Bosch (approximately 1480 - 1505), Museo Prado, Madrid, Spain.

https://commons.wikimedia.org/wiki/File:The_Garden_of_ Earthly_Delights_by_Bosch_High_Resolution_2.jpg 
(dairy products such as yoghurt as well as supplements). A remarkable outcome of our study is that none of the English (online) sources had a completely adequate definition of probiotics. A limited search in non-English, online dictionaries showed that Dictionario Priberam, a Portuguese online dictionary had a complete and correct description of probiotics (https://dicionario. priberam.org/probi\%C3\%B3tico). In a follow-up study we will investigate how probiotics are $d$ escribed in other languages of the world.

\section{Acknowledgments}

No external funding was used for this study. Costs associated with retrieval and analysis of bibliographic data were covered by University College Roosevelt.

\section{Conflict of Interest}

All authors declare no conflicts of interest in this paper.

\section{References}

1. World Health Organization (2001) Health and nutritional properties of probiotics in food including powder milk with live lactic acid bacteria. Food and Agricultural Organization of the United Nations and World Health Organization.

2. Hill C, Guarner F, Reid G, Gibson GR, Merenstein DJ, et al. (2014) The International Scientific Association for Probiotics and Prebiotics consensus statement on the scope and appropriate use of the term probiotic. Nat Rev Gastroenterol Hepatol 11: 506-514.

3. EFSA on Dietetic Products, Nutrition and Allergies (NDA) (2011) Guidance on the scientific requirements for health claims related to gut and immune function. EFSA Journal 9: 1984.

4. Pratt AJ (2011) Prebiological evolution and the metabolic origins of life. Artif Life 17: 203-217. 
Supplementary Table 1: Descriptions of the term "probiotics" in online and printed English dictionaries.

\section{Source}

Description

Online Only Sources (Accessed $31^{\text {st }}$ October 2018)

Vocabulary.com

https://www.vocabulary.com/

MacMillan

https://www.macmillandictionary.com/

Wiktionary

https://www.wiktionary.org/

Dictionary.com

https://www.dictionary.com/

A beneficial bacterium found in the intestinal tract of healthy mammals; often considered to be a plant.

Microorganisms (= very small living things) that are believed to make you more healthy if you eat them. Probiotics may decrease the incidence of respiratory tract infections.

(Bacteriology) A food or dietary supplement, such as yogurt, containing live bacteria for therapeutic reasons.

1. A usually dairy food or a dietary supplement containing live bacteria that replace or add to the beneficial bacteria normally present in the gastrointestinal tract.

The Free Dictionary

https://www.thefreedictionary.com/

2. A bacterium in such a food or dietary supplement.

1. A nutraceutical containing live bacteria or yeast that supplements normal gastrointestinal flora, given especially after depletion of flora caused by infection or ingestion of an antibiotic drug.

Your Dictionary

2. A bacterium that supplements normal gastrointestinal flora. (Entry from Webster's New World Collegiate Dictionary)

http://www.yourdictionary.com/

Urban Dictionary

https://www.urbandictionary.com/

A substance that stimulates the growth of beneficial bacteria in the alimentary and gastrointestinal tracts and thus benefits the host as well.

Online versions of printed Sources; Accessed - 27 $7^{\text {nd }}$ October 2018

American Heritage Dictionary (AHD)

https://ahdictionary.com/

The Chambers Dictionary

https://chambers.co.uk

Collins English Dictionary

https://www.collinsdictionary.com/dictionary/english

New Oxford American Dictionary (NOAD)

www.oxfordreference.com (accessed via the Utrecht University Library)

\section{Oxford Dictionary of English}

www.oxfordreference.com (accessed via the Utrecht University Library)

Oxford English Dictionary (OED)

http://www.oed.com/

Webster's Third New International Dictionary

https://www.merriam-webster.com/dictionary

\section{Printed dictionaries}

The American Heritage Dictionary of the English Language (1992 edition)

The Chambers Dictionary (1998 edition)

Collins English Dictionary (1998 edition)

Concise Oxford English Dictionary (COED) (2011 edition)

New Oxford American Dictionary (NOAD)

(2010 edition)

\section{No word definition found.}

Alternative medicine treatment by taking into the body bacteria that support the useful and harmless bacteria that are already in the body against the harmful ones.

A therapeutic treatment involving the ingestion of harmless bacteria.

(adjective) Denoting a substance that stimulates the growth of microorganisms, especially those with beneficial properties (such as those of the intestinal flora). Denoting substance that stimulates growth of microorganisms

(adjective) Denoting a substance that stimulates the growth of microorganisms, especially those with beneficial properties (such as those of the intestinal flora). Denoting substance that stimulates growth of microorganisms

1. A substance that promotes the growth of organisms; esp. a metabolite produced by one microorganism that promotes the growth of other microorganisms.

2. A microorganism, or (in early use) a substance, used to restore or modify the composition of the microflora of a compartment of a body (esp. the intestines or rumen); a preparation of such microorganisms. A microorganism (such as lactobacillus) that when consumed (as in a food or a dietary supplement) maintains or restores beneficial bacteria to the digestive tract. also: a product or preparation that contains such microorganisms.

\section{No word definition found.}

Treatment by the ingestion of the bacteria that support the useful and harmless bacteria in the body against the harmful ones.

No word definition found.

Denoting a substance which stimulates the growth of microorganisms, especially beneficial ones such as those of the intestinal flora.

A probiotic substance or preparation, adj: denoting a substance that stimulates the growth of microorganisms, esp. Those with beneficial properties (such as those of the intestinal flora. 


\begin{tabular}{|c|c|}
\hline $\begin{array}{l}\text { The New Oxford American Dictionary } \\
\text { (2001 edition) }\end{array}$ & No word definition found. \\
\hline $\begin{array}{l}\text { Oxford English Dictionary (OED) } \\
\text { (1989 edition) }\end{array}$ & Prebiological, prebiotic. \\
\hline $\begin{array}{l}\text { The New Oxford Dictionary of English } \\
\text { (1998 edition) }\end{array}$ & No word definition found. \\
\hline $\begin{array}{l}\text { Shorter Oxford English Dictionary (SOED) } \\
\text { (2007 edition) }\end{array}$ & No word definition found. \\
\hline $\begin{array}{l}\text { Webster's Third New International Dictionary } \\
\text { (1976 edition) }\end{array}$ & No word definition found. \\
\hline $\begin{array}{l}\text { Collins COBUILD Advanced Learner's English } \\
\text { Dictionary ( } 2003 \text { edition) }\end{array}$ & No word definition found. \\
\hline $\begin{array}{l}\text { Collins COBUILD Advanced Dictionary } \\
\text { (2009 edition) }\end{array}$ & No word definition found. \\
\hline $\begin{array}{l}\text { The Penguin English Dictionary } \\
\text { (2003 edition) }\end{array}$ & $\begin{array}{l}\text { A preparation containing bacteria beneficial to health, especially to the } \\
\text { healthy functioning of the gut. }\end{array}$ \\
\hline $\begin{array}{l}\text { Longman Dictionary of Contemporary English New } \\
\text { Edition (1987 edition) }\end{array}$ & No word definition found. \\
\hline The Times English Dictionary (2000 edition) & No word definition found. \\
\hline $\begin{array}{l}\text { Merriam-Webster's Collegiate Dictionary } \\
\text { (2008 edition) }\end{array}$ & $\begin{array}{l}\text { A preparation (as a dietary supplement) containing live bacteria (as } \\
\text { lactobacilli) that is taken orally to restore beneficial bacteria to the } \\
\text { body, also: A bacterium of such a preparation. }\end{array}$ \\
\hline $\begin{array}{l}\text { The American Heritage Dictionary of the English } \\
\text { Language ( } 2000 \text { edition) }\end{array}$ & No word definition found. \\
\hline
\end{tabular}

Supplementary Table 2: Descriptions of the term "antibiotics" in online and printed English dictionaries.

\section{Source}

Online Only Sources; Accessed 31 ${ }^{\text {st }}$ October 2018

Vocabulary.com

\section{Description}

https://www.vocabulary.com/ MacMillan

https://www.macmillandictionary.com/

Wiktionary

https://www.wiktionary.org/

Dictionary.com

https://www.dictionary.com/

\section{The Free Dictionary}

https://www.thefreedictionary.com/

\section{YourDictionary}

http://www.yourdictionary.com/

Urban Dictionary

https://www.urbandictionary.com/

\section{Online version of print sources; Accessed - 27 ${ }^{\text {nd }}$ October 2018}

American Heritage Dictionary (AHD)

https://ahdictionary.com/ diseases.
A chemical substance derivable from a mold or bacterium that can kill microorganisms and cure bacterial infections

A drug that cures illnesses and infections caused by bacteria. Doctors often give people a course of antibiotics, when they have to take a fixed amount of medicine each day for several days.

(pharmacology) Any substance that can destroy or inhibit the growth of bacteria and similar microorganisms.

Any of a large group of chemical substances, as penicillin or streptomycin, produced by various microorganisms and fungi, having the capacity in dilute solutions to inhibit the growth of or to destroy bacteria and other microorganisms, used chiefly in the treatment of infectious diseases. A substance, such as penicillin or erythromycin, produced by or derived from certain microorganisms, including fungi and bacteria, that can destroy or inhibit the growth of other microorganisms, especially bacteria. Antibiotics are widely used in the prevention and treatment of infectious

The definition of antibiotic is a medicine that helps a person or animal heal from an infection by destroying or limiting harmful microorganisms.

A type of drug that was (officially) discovered in 1928 when Sir Alexander Fleming was cleaning out his petri dishes then saw a mold on one of them. He studied it, and noticed that all of the bacteria around the mold had been killed. Now, we use these "wonder drugs" to save people who (over a hundred years ago) would have died a painful death from bacterial infections. Now, unfortunately, they are overused and used when unnecessary, and can lead to antibiotic resistance. Includes penicillin, amoxicillin, streptomycin, neomycin, paromomycin, cefepime, cefprozil, aztreonam, ciprofloxacin, etc.

A substance, such as penicillin or erythromycin, produced by or derived from certain microorganisms, including fungi and bacteria, that can destroy or inhibit the growth of other microorganisms, especially bacteria. Antibiotics are widely used in the prevention and treatment of infectious diseases. 
The Chambers Dictionary

https://chambers.co.uk

Collins English Dictionary

https://www.collinsdictionary.com/dictionary/english

New Oxford American Dictionary (NOAD)

www.oxfordreference.com (accessed via the

Utrecht University Library)

Oxford Dictionary of English

www.oxfordreference.com (accessed via the

Utrecht University Library)

Oxford English Dictionary (OED)

http://www.oed.com/

Webster's Third New International Dictionary

https://www.merriam-webster.com/dictionary

Printed dictionaries

The American Heritage Dictionary of the English Language (1992 edition)

The Chambers Dictionary (1998 edition)

Collins English Dictionary (1998 edition)

Concise Oxford English Dictionary (COED)

(2011 edition)

New Oxford American Dictionary (NOAD)

(2010)

The New Oxford American Dictionary

(2001 edition)

Oxford English Dictionary (OED)

(1989 edition)

The New Oxford Dictionary of English

(1998 edition)

Shorter Oxford English Dictionary (SOED)

(2007 edition)

Webster's Third New International Dictionary

(1976 edition)

Collins COBUILD Advanced Learner's English

Dictionary (2003 edition)

Collins COBUILD Advanced Dictionary

(2009 edition)

The Penguin English Dictionary

(2003 edition)

Longman Dictionary of Contemporary English New A medical substance, such as penicillin, that is produced by living things Edition (1987 edition)
A substance, produced or derived from a micro-organism, that can selectively destroy or inhibit other bacteria or fungi without damaging the host, eg: Penicillin, widely used in the treatment of bacterial infections.

Medical drugs used to kill bacteria and treat infections.

A medicine (such as penicillin or its derivatives) that inhibits the growth of or destroys microorganisms.

A medicine (such as penicillin or its derivatives) that inhibits the growth of

One of a class of substances produced by living organisms and capable of destroying or inhibiting the growth of micro-organisms; spec. any of these substances used for therapeutic purposes. Also used of synthetic organic compounds having similar properties.

A substance produced by or a semisynthetic substance derived from a microorganism and able in dilute solution to inhibit or kill another microorganism.

A substance, such as penicillin or streptomycin, produced by or derived from certain fungi, bacteria, and other organisms, that can destroy or inhibit the growth of other microorganisms. Antibiotics are widely used in the prevention and treatment of infectious diseases.

Inimical to life; inhibiting the growth of another organism, used esp of a substance produced by micro-organisms which, in dilute solution, has the capacity to inhibit the growth of, or to destroy, micro-organisms causing infectious diseases; relating to antibiosis.

Any of various chemical substances, such as penicillin, streptomycin, neomycin, and tetracycline, produced by various microorganisms, esp. fungi, or made synthetically and capable of destroying or inhibiting the growth of microorganisms, esp. bacteria.

A medicine that inhibits the growth of or destroys microorganisms.

A medicine (such as penicillin or its derivatives) that inhibits the growth of or destroys microorganisms.

A medicine (such as penicillin or its derivatives) that inhibits the growth of or destroys microorganisms.

Hence as sb., an antibiotic substance: one of a class of substances produced by living organisms and capable of destroying or inhibiting the growth of micro-organisms; spec. any of these substances used for therapeutic purposes. Also used of synthetic organic compounds having similar properties.

A medicine (such as penicillin or its derivatives) that inhibits the growth of or destroys microorganisms.

A substance which is capable of destroying or inhibiting the growth of bacteria or other microorganisms: spec. one that is produced by another microorganism (or is a synthetic analogue of a microbial product) and is used therapeutically.

A substance produced by a microorganism (as a bacterium or a fungus) and in dilute solution having the capacity to inhibit the growth of or kill another microorganism (as a disease germ).

Antibiotics are medical drugs used to kill bacteria and treat infections.

Antibiotics are medical drugs used to kill bacteria and treat infections.

A substance, such as penicillin, able to inhibit the growth of or kill microorganisms, esp. bacteria. and is able to destroy or stop the growth of harmful bacteria that have entered the body. or destroys microorganisms. 
The Times English Dictionary (2000 edition)

Merriam-Webster's Collegiate Dictionary

(2008 edition)

The American Heritage Dictionary of the English Language (2000 edition)
Any of various chemical substances, such as penicillin, streptomycin, neomycin, and tetracycline, produced by various microorganisms, esp. fungi, or made synthetically and capable of destroying or inhibiting the growth of microorganisms, esp. bacteria.

A substance produced by or a semisynthetic substance derived from a microorganism and able in dilute solution to inhibit or kill another microorganism.

A substance, such as penicillin or streptomycin, produced by or derived from certain fungi, bacteria, and other organisms, that can destroy or inhibit the growth of other microorganisms. Antibiotics are widely used in the prevention and treatment of infectious diseases. 